\title{
CECHY ŚRODKÓW ZAPISU I PRZEKAZU INFORMACJI
}

Porozumiewanie się ludzi między sobą, przyswajanie, przetwarzanie i przekazywanie informacji to odwieczne aspekty funkcjonowania społeczności ludzkiej. $\mathrm{Na}$ równi z potrzebami komunikacyjno-poznawczymi człowiek posiada właściwe sobie potrzeby gromadzenia (magazynowania, akumulowania) wytworów kultury. Pierwszym systemem umożliwiającym efektywne komunikowanie się był język (mowa). Następnym etapem po języku było wynalezienie pisma, choć nie są to zjawiska porównywalne. Mowa stanowi produkt naturalnej ewolucji (o czym świadczy m.in. fakt, że jest to umiejętność uniwersalna), trudno więc mówić tu o wynalazku. Mowa nie wymagała żadnych narzędzi (instrumentów), przy tym sposobie komunikowania człowiek wykorzystywał naturalne organy. Także przechowywanie informacji było w tym pierwszym etapie procesem naturalnym, jedynym nośnikiem informacji (magazynem) była pamięć ludzka. Wiedza zdobyta w doświadczeniu życiowym jednostki była ulotna, przekazywanie jej następnym pokoleniom odbywało się albo za pośrednictwem genów albo za pomocą osobistych kontaktów (przekaz ustny), nie pozostawiając żadnego utrwalonego zapisu. Wynalazek pisma przełamal dotychczasowe ograniczenia w komunikacji społecznej - bariery czasowe i przestrzenne. Utrwalona za pomocą zapisu informacja mogła „przeżyć" swego twórcę, a samo przemieszczanie informacji stało się możliwe bez konieczności przemieszczania jej nadawcy. Umożliwiło to gromadzenie i kumulowanie doświadczeń i wiedzy poszczególnych jednostek a nawet pokoleń i wykorzystywanie ich przez pokolenia następne; pojawia się inny rodzaj „pamięci” niż mózg ludzki. Stopniowo powstają coraz to nowe układy (systemy) komunikacyjne, których wyłonienie związane jest $z$ wprowadzaniem nowych urządzeń do zapisu, nadawania lub odbioru informacji. Tak więc historię i rozwój układów komunikacyjnych rozpatrywać można w kategoriach rozwoju metod i narzędzi w nich stosowanych. Aby wskazać różnice między poszczególnymi systemami komunikacyjnymi należy wyodrębnić podstawowe elementy aktu komunikacyjnego, przedstawić ich cechy i formy oraz relacje zachodzące między nimi.

\section{Elementy układu komunikacyjnego}

W teorii komunikacji w jednostkowym procesie (akcie) przekazu informacji wyodrębnia się co najmniej cztery podstawowe elementy warunkujące ten proces; musi istnieć jakieś źródło informacji, nadawca wydobywający tę informację ze źródła, odbiorca, któremu nadawca przekazuje informację, oraz łączące nadawcę 
z odbiorcą środowisko materialne, za pomocą którego informacja jest przekazywana, zwane kanałem informacyjnym.

Najprostszym sposobem przkazywania informacji między dwojgiem ludzi jest dialog między nimi. Obaj rozmówcy są na przemian nadawcami i odbiorcami informacji (przekazywanej za pomocą mowy), kanałem zaś jest powietrze przenoszące dźwięki mowy (fale głosowe). Jeśli proces przekazu informacji nie ma charakteru naturalnego, tj. wykorzystującego jedynie organy i zmysły człowieka (jak jego aparat mowy, słuch, wzrok), wystąpić mogą dodatkowo w procesie komunikacyjnym instrumenty informacyjne. Jeśli informację chcemy przekazać w przestrzeni (do wykorzystania w miejscu fizycznie oddalonym) mamy do czynienia z procesem przesyłania informacji, jeśli w czasie (do późniejszego wykorzystania) - z procesem utrwalania (zapamiętywania). Zgodnie z tym wyróżnieniem wyodrębnić można wśród instrumentów informacyjnych takie, które służą do zapisu informacji i jej przechowywania, np. rylec, pióro, maszyna do pisania lub druku, oraz takie, które służą do przesyłania informacji, np. wszelkie systemy telekomunikacyjne, jak telegraficzny, radiowy, telefoniczny.

Jak już wspomniano, jedną z form magazynowania informacji jest pamięć ludzka, dlatego też urządzenia służące do przechowywania informacji nazywane są czasami urządzeniami pamięciowymi. Informacja może być poddana procesowi przechowywania tylko wówczas, gdy została utrwalona, tj. zapisana na jakimś materiale (nośniku informacji) za pomocą znaków, symboli. Wynikiem procesu utrwalania jest dokument. Tak więc $w$ dokumencie wyróżnić można nośnik (materiał, na którym informacja została utrwalona oraz jego formę), sygnał (tj. materialną, np. akustyczną lub graficzną strukturę danego zapisu) oraz zawartość treściową przekazywaną za pomocą sygnału.

Nadawca, aby przekazać informację musi jej nadać jakąś formę, musi ją zakodować, odbiorca, aby odebrać, musi ją odkodować. Człowiek wykorzystuje do kodowania informacji narządy mowy lub system mięśniowy, który wytwarza gesty lub powoduje zapis. W obecnych czasach nadawca ma do wyboru szereg środków przekazu (kanałów informacyjnych). Informację można przekazać w formie pisemnej, w jednym, kilku lub tysiącach egzemplarzy, w formie ustnej, bezpośredniej, skierowanej do jednej osoby lub grupy osób, bądź też do kilku milionów za pomocą środków masowego przekazu. Nadawca ma więc do wyboru kanał (np. wizualny lub słuchowy), a w obrębie kanału także wybór nośnika i instrumentów, np. może zadecydować, czy nagrać na płycie czy na taśmie magnetofonowej, opublikować w czasopiśmie czy w książce, zapisać ręcznie czy przy pomocy maszyny do pisania lub procesora tekstu.

Kanał informacyjny to droga, która umożliwia przepływ informacji od nadawcy do odbiorcy, środek fizyczny (medium), który doprowadza sygnał od przekazującego informację do jej potencjalnego użytkownika. Za kryterium podziału kanałów uważa się zazwyczaj nośnik informacji lub sygnał umożliwiający przekazanie informacji (tzn. wyróżnia się kanały wizualne lub audialne), choć w zasadzie podział ten związany jest raczej z charakterem odbioru informacji przez czlowieka (czy za pomocą wzroku czy za pomoca słuchu). Wśród licznych kanałów przepływu informacji tradycyjnie wyróżnia się trzy podstawowe grupy. Pierwszą tworzą kanały, 
przez które następuje przekazanie informacji za pomocą mowy (języka mówionego). Wymiana informacji odbywa się w tym wypadku przez bezpośrednią rozmowę, za pomocą systemu telefonicznego lub radiowego. Do drugiej grupy zaliczane są kanały, gdzie przepływ następuje za pomocą pisma lub druku (języka pisanego); podstawowymi formami są tu list, książka, czasopismo, gazeta. Ostatnią grupę tworzą kanały, gdzie przekazywanie informacji odbywa się za pomoca obrazów, zarówno obrazu nieruchomego (rysunki, fotografie, plakaty), jak i ruchomego (film, transmisja telewizyjna). Wybór kanału zależy od wielu czynników, m.in. od cech treściowych nadawanej informacji, od jej przeznaczenia, od rodzaju i dostępności technicznych środków przekazu, itp.

Proces przekazywania informacji, czyli przemieszczanie informacji w przestrzeni, dotyczyć może albo informacji utrwalonej, wtedy mamy do czynienia z przemieszczaniem informacji wraz z jej nośnikiem (pod postacią dokumentu), albo informacji nie utrwalonej, a wtedy polega on na przemieszczaniu sygnału w kanale informacyjnym. W tym wypadku procesowi temu towarzyszy często transformacja sygnału, np. sygnał akustyczny przekształcony jest na sygnał magnetyczny. Transformacja dokonywana jest w celu umożliwienia lub usprawnienia procesu przesyłania sygnału (transmisji). Większość sygnałów wykorzystywanych obecnie do transmisji jest nieodbieralna przez człowieka, np. impulsy elektryczne, magnetyczne, dlatego aby zostały one zrozumiane muszą być poddane kolejnej transformacji na sygnały przez niego odbieralne (które umie odkodować), tj. na audialne lub wizualne (czasami na dotykowe). Dokonywane jest to za pomocą specjalnych urządzeń - odbiorników.

Duże znaczenie $w$ polepszaniu procesów przekazywania informacji mają coraz doskonalsze urządzenia do komunikacji (łączności). Przyspieszają one i usprawniają przepływ informacji, zapewniają łatwość zapisywania (kodowania) i odbierania (odkodowywania) informacji, zwiększają trwałość nośnika i niezawodność przekazu.

\section{Cechy nośnika informacji}

Nasuwa się pytanie, jakie są tendencje rozwojowe w zakresie nośników informacji i jakie cechy decydują o przydatności i popularności nośnika? Najbardziej widoczną i najczęściej podkreślaną cechą obecnego rozwoju technologii informacyjnej jest miniaturyzacja nośnika przy jednoczesnym zwiększeniu jego pojemności. Miniaturyzacja umożliwia przestrzenne ograniczenie zbiorów informacji typu archiwum lub biblioteki (oszczędność miejsca). Miniaturyzacja dotyczy nie tylko samego nośnika, lecz także urządzeń służących do zapisu i odczytu (odbioru) informacji, np. zastąpienie systemu lampowego tranzystorowym zminiaturyzowało radioodbiorniki i komputery.

Zwiększeniu pojemności nośnika w celu umożliwienia gromadzenia (magazynowania) wciąż rosnących zasobów ludzkiej wiedzy służyło wprowadzenie mikrodokumentów (mikrofilmów i mikrofisz), jednak prawdziwa rewolucja w tej dziedzinie nastapiła dopiero wraz z rozwojem techniki komputerowej. Już taśmy i dyski magnetyczne umożliwily przechowywanie ogromnych zasobów informacji w po- 
równaniu z nośnikami tradycyjnymi, ale dopiero technologia dysków optycznych (CD ROM, WORM, itp,) oferuje wprost nieograniczoną pojemność przy stosunkowo niewielkim zapotrzebowaniu przestrzennym.

Dyski optyczne posiadają jeszcze inne zalety, są trwałe i tanie. Ta druga cecha brana jest często pod uwagę przy ocenie lub wyborze nośnika, a składa się na nią niski koszt wytwarzania nośnika (co związane jest m.in. z dostępnością surowców), oraz jego powielania i rozpowszechniania. Postęp technologiczny prowadzi do ciągłej redukcji kosztów, czego przykładem może być obniżenie cen książek dzięki wynalazkowi druku. Czasami nie uświadamiamy sobie, jak często niższe koszty lub wygoda w korzystaniu decydują o wyparciu jednego środka komunikacji przez inny. Teatr został w znacznym stopniu zastąpiony kinem, a kino telewizją (choć „jakość" obioru jest coraz gorsza) nie tylko dlatego, że wygodniejsze jest korzystanie (bliżej odbiorcy), ale głównie dlatego, że telewizja jest tańsza od kina, a kino od teatru. Prawdopodobnie koszty decydują też o stopniowym wypieraniu usług pocztowych opartych na transporcie przez tańszą (a przy tym szybsza) pocztę elektroniczną.

Przy omawianiu kosztu nośnika wspomnieliśmy, że zależy on m.in. od dostępności materiału służącego do jego wytworzenia. Łączy się z tym jeszcze jeden czynnik, tym razem pozaekonomiczny, podnoszony szczególnie często w ostatnich latach - ochrona środowiska naturalnego. Czynnik ten może doprowadzić do wyeliminowania lub przynajmniej ograniczenia stosowania papieru na korzyść nośników elektronicznych lub do zastapienia papieru podobnym mu w funkcjach „papierem sztucznym”, syntetycznym. Obecne społeczeństwo zużywa ogromne ilości papieru (w krajach wysoko rozwiniętych ok. $50 \mathrm{~kg}$ rocznie na jednego mieszkańca) i według ocen wielu specjalistów tempa tego nie wytrzyma środowisko naturalne. Dlatego coraz częściej roztacza się wizję „bezpapierowego spoleczeństwa" i postuluje przechodzenie na media elektroniczne, prezentujące informację wynikową na ekranie. Podobnie jak telegraf czy korespondencja zostały w znacznym stopniu wyparte przez telefon nie zużywający papieru, tak też informacja na nośnikach elektronicznych może zastąpić „dokumentację papierową”, przy możliwości wydruku w uzasadnionych przypadkach. Obecne nawyki komunikacyjne spoleczeństwa wychowanego na dokumentacji papierowej są silniejsze i wydruki komputerowe stosowane są zbyt często. Już teraz jednak zaobserwowano zmniejszenie zużycia papieru w niektórych domach dzięki częściowemu zastąpieniu tradycyjnych gazet telegazetą lub czasopismem elektronicznym. Media elektroniczne są wyjątkowo przychylnie oceniane przez zwolenników ochrony przyrody, gdyż zużywają znacznie mniej energii, pracy ludzkiej i surowców ${ }^{1}$. Co prawda telewizyjne i komputerowe sieci kablowe, tak jak poprzednio sieci telefoniczne, zużywały dużo miedzi, ale i ta wada zostaje wyeliminowana dzięki przejmowaniu ciężaru transmisji dalekiego zasięgu przez satelity telekomunikacyjne oraz zastępowaniu kabli włóknami optycznymi. Włókna optyczne wytwarzane są z najpowszechniejszego surowca na ziemi, jakim jest dwutlenek krzemu (piasek), a przy tym zapewniaja wyższa jakość transmisji i większą pojemność (pojedyncze włókno może przenieść tysiące rozmów telefonicznych). 
Do oszczędności surowców prowadzi także inna cecha nośnika, jaką jest możliwość jego wielokrotnego wykorzystania do zapisu informacji. Ogromny minus najpowszechniejszego obecnie nośnika, jakim jest papier, stanowi jego jednokrotne wykorzystanie; raz zapisany nie może być ponownie użyty, podczas gdy większość elektronicznych nośników informacji może być powtórnie wykorzystana po skasowaniu informacji raz zapisanej. Trzeba jednak przyznać, że nieścieralność (niemożność skasowania) raz zapisanej informacji ma też swoje plusy (wierność zapisu, zabezpieczenie przed skasowaniem, prawo autorskie, itp.), dlatego większość stosowanych obecnie typów środków komunikacji ma swoje ścieralne i nieścieraine odpowiedniki, np. taśma magnetofonowa - płyta (gramofonowa lub kompaktowa), taśma magnetowidowa - taśma filmowa, dysk magnetyczny - dysk optyczny typu CD ROM, itp. Przy takim zestawieniu jeszcze bardziej rażący wydaje się być brak ścieralnego odpowiednika dla najpopularniejszego nośnika, jakim jest papier (gdyż trudno za taki odpowiednik uznać tablice). Rozwiązaniem może tu być wynalezienie „zmywalnego" papieru syntetycznego lub zastosowanie do zapisu znaków substancji mniej trwałej niż atrament lub tusz i łatwiejszej do usunięcia niż ścieranie ołówka gumką. Wielokrotne wykorzystanie papieru dawałoby ogromne oszczędności i usatysfakcjonowałoby obrońców środowiska naturalnego.

$Z$ tendencją do miniaturyzacji związane jest dążenie do coraz większej portatywności nośnika (łatwości przenoszenia), zależnej w znacznej mierze od jego ciężaru, rozmiaru i poręczności. Książka na papierze zawsze była łatwiejsza do korzystania i przenoszenia od kamienia i tabliczek (drewnianych, glinianych czy metalowych), a jej rozwój zmierzal do coraz większej portatywności. Po powstaniu książki drukowanej zmianie ulegać zaczęła też jej forma zewnętrzna, np. okładki drewniane zastąpiono lżejszymi tekturowymi; z czasem wprowadzono książkę kieszonkową, jeszcze bardziej poręczną. Podobne dążenie obserwujemy przy rozwoju uządzeń do zapisu i odbioru informacji, np. wprowadzenie przenośnego radia tranzystorowego, walkmana do odtwarzania taśm z nagraniami dźwiękowymi czy przenośnego komputera (lap-top computer). Umożliwia to korzystanie z tych mediów nie tylko $w$ domu, lecz zabranie ich ze sobą w podróż, do pracy lub przeniesienie do innego pomieszczenia.

Od formy nośnika i sposobu odczytu zależy też jeszcze inna cecha środka komunikacji, mająca ogromny wpływ na sposób korzystania z informacji - ciągłość lub dyskretność. Związane jest to z możliwością bezpośredniego dostępu do jednostkowej informacji znajdującej się w zbiorze lub wybranego fragmentu długiego tekstu. Nośnik ciągly, jakim jest np. taśma magnetofonowa, mikrofilmowa, magnetyczna, magnetowidowa lub perforowana ma sekwencyjny sposób zapisu, co sprawia, że przy wyrywkowym wyszukiwaniu informacji konieczne jest przewijanie taśmy od jej początku do miejsca, w którym znajduje się pożądana informacja. Powoduje to szybsze mechaniczne zużycie nośnika (będące skutkiem ciągłego „prewijania") i wydłuża czas dostępu do informacji. Dlatego dla zbiorów informacyjnych często wykorzystywanych bardziej praktyczny jest nośnik umożliwiający swobodny dostęp, np. dysk magnetyczny, płyta, mikrofisza, gdyż dotarcie do określonej informacji trwa tu o wiele krócej i nie wymaga przeszukiwania całego zbioru. Podobnie jak przy wielokrotności zapisu, tak i w tym wypadku większość 
nośników ma swoje odpowiedniki ciagłe i dyskretne, np. taśma magnetofonowa phyta, taśma perforowana - karta perforowana, mikrofilm - mikrokarta, karta magnetyczna - dysk magnetyczny, itp. Za dyskretny odpowiednik książki w postaci zwoju uznać można kodeks.

Inną widoczną cechą współczesnych nośników informacji jest zdolność przekazywania więcej niż jednego rodzaju sygnału, formy informacji. Tradycyjne nośniki mogły utrwalać informację jednego typu, np. taśma magnetofonowa - tylko dźwięk (informacja słuchowa), fotografia - tylko obraz (informacja wizualna). Istnialy już wprawdzie dawniej nośniki utrwalające informację mieszaną, np. nośnik papierowy mógł być wykorzystywany do jednoczesnego zapisu informacji tekstowej i obrazowej (ilustracja), jednak dopiero najnowsze środki przekazu poszerzyły zakres utrwalania i odtwarzania zróżnicowanych form informacji. Telewizja umożliwiła przekaz nagrania dźwiękowego (mowa, muzyka), zapisu graficznego, tekstowego, filmowego, choć przy wykorzystaniu różnych kanałów (inny dla dźwięku, inny dla obrazu). Dopiero dysk optyczny pozwolił na zapis tą samą techniką (laserowa) i przy pomocy tego samego systemu znaków (kodu binarnego) muzyki, głosu, grafiki, tekstu, obrazu ruchomego i nieruchomego, dodatkowo dając możliwość komputerowego przetwarzania tych danych. Środki przekazu tego typu, ze względu na swoje wielorakie funkcje i zróżnicowane formy prezentacji informacji nazywane są multimediami.

Nowoczesne środki przekazu charakteryzują się dążeniem do coraz większej wierności odtwarzania (np. ostrość, kolor, wielkość obrazu), oczywiście do pewnych granic wyznaczonych przez możliwości percepcyjne człowieka, np. rozwój magnetofonu i adapteru (odtwarzacza kompaktowego) już prawie zamarł, gdyż jakość odtwarzania jest już tak wysoka, że dalsze jej podnoszenie jest nie do wykrycia przez ludzkie ucho. Nie można natomiast w rozwoju nośnika informacji zauważyć dążenia do coraz większej jego trwałości (odporności na zniszczenie). Związane jest to prawdopodobnie z coraz szybszą dezaktualizacją informacji wynikającą $z$ wzrastającego tempa rozwoju nauki i techniki. Odstępstwem od tego trendu w zakresie zapisu coraz bardziej „ulotnego”, podatnego na zniszczenie są dyski optyczne, charakteryzujące się znacznie większą żywotnością, przynajmniej w stosunku do pozostałych nośników elektronicznych.

\section{Współistnienie środków komunikacji}

Ewolucja metod i środków komunikacji, czyli form zapisu i przekazu informacji, odznacza się pewną właściwością - nowo pojawiające się formy nie wypieraja całkowicie starych, ale są jakby na nie „nałożone". W miarę pojawiania się nowych środków dotychczasowe nie zanikają, lecz przekazawszy część swoich funkcji nowo powstałym rozpoczynają nowe życie o ograniczonym zasięgu oddziaływania, wypełniając bardziej wyspecjalizowane zadania.

Funkcje, które stare media zatrzymują to te, które wypełniane były przez nie w sposób zadawalający, natomiast te funkcje, które mogą być zaspokajane lepiej (sprawniej, taniej, szybciej) przez nowo powstałe media są im odbierane. Najczęściej jednak nowo tworzone systemy komunikacyjne nie służą zastąpieniu starych, 
a raczej poszerzeniu całego pola komunikacji społecznej, wchodzą na nowe obszary dotychczas nie wykorzystywane, oferują nową jakość, uzupełniają i wzbogacają istniejące kanały informacyjne dając możliwości dotychczas nieosiągalne.

Tak więc wprowadzenie nowych form komunikacji nie eliminuje żadnej $z$ form tradycyjnych, ale jest w stosunku do zastanego systemu komunikacji komplementarne, umożliwiając jednocześnie większą specjalizację funkcji dotychczasowych środków komunikowania się oraz ujęcie w zorganizowany strumień większej ilości informacji i usprawnienie jej dystrybucji. Nie mamy tu do czynienia z zamianą jednego sposobu komunikowania się na drugi, lecz z ich koegzystencją. Pismo nie wyparło mowy, tak jak wcześniej wprowadzenie języka nie wyeliminowało gestów jako środka komunikacji ${ }^{2}$. Podobnie jak rozwój pisma nie spowodował zaniku bezpośredniego kontaktowania się za pomocą mowy, tak też zapotrzebowanie na większą liczbę egzemplarzy dziet, doprowadziwszy do wynalazku druku nie wyeliminowało rękopiśmiennictwa (zapisu ręcznego), np. notatki, zapis na tablicy lub folii, korespondencja. Pojawienie się i szybki rozwój czasopiśmiennictwa nie doprowadziło do obumarcia książki, teatr nie zginął wraz z powstaniem kina, wynalazek telewizji nie spowodował końca radia, a telefon nie wypart telegrafii.

Czy jednak rzeczywiście wszystkie stare uklady komunikacyjne przetrwały, i to $w$ nie zmienionej formie? Prześledzenie historii rozwoju komunikacji wskazuje, że niektóre z tradycyjnych środków zapisu i przekazu zniknęly całkowicie (np. sygnały dymne lub ogniowe), a inne funkcjonują wprawdzie do dziś, ale tylko w szczątkowej, reliktowej formie, $\mathrm{np}$. bicie w dzwony, kamienne tablice pamiątkowe, forma zwoju dla dokumentów szczególnie ważnych lub uroczystych (dyplom, akt erekcyjny, ważna umowa). Nie stanowią już systemów komunikacyjnych wykorzystywanych do przekazu informacji, lecz pełnią funkcje środków pomocniczych, związanych z tradycją, symbolizujących pewne wartości niezależne od samego komunikatu, np. kamień jako materiał do napisów nagrobnych lub tablic pamiątkowych będący symbolem „ponadczasowości”, odporności na przepływ czasu, więzi z poprzednimi i przyszłymi pokoleniami (jako najstarszy materiał do zapisu i jednocześnie najtrwalszy).

Innym charakterystycznym zjawiskiem jest przemiana zachodząca w obrębie samego układu komunikacyjnego; rzadko które elementy starego układu pozostają nie zmienione w miarę rozwoju techniki. Co prawda, komputer nie wyparł książki i czasopisma, ale całkowicie zrewolucjonizował proces ich produkcji. Obecny, całkowicie zautomatyzowany proces druku w niczym nie przypomina metod wytwarzania książki rękopiśmiennej w Średniowieczu czy w czasach Gutenberga, choć produkt końcowy jest w jakiejś mierze podobny. Czy współczesną pocztę można porównać z pocztą konną lub z kurierami w dawnych czasach? Pismo ręczne nie zostało wyparte przez druk, ale zmianie uległy wszystkie wykorzystywane instrumenty (narzędzia, materiały). Tak jak pędzelek został zastąpiony gęsim piórem, następnie stalówką, piórem wiecznym, długopisem lub flamastrem, tak też farba zostala zastąpiona atramentem (o zmieniającym się składzie chemicznym), a obecnie tuszem. Tańszy, wygodniejszy instrument wypiera poprzedni. Jeszcze bardziej widoczne są zmiany w zakresie materiału (podłoża), służącego do utrwalenia - nośnika i jego formy. Kamień został wyeliminowany przez materiały lżejsze, 
tańsze, poręczniejsze, łatwiejsze do obróbki i przenoszenia. Tak jak zniknał papirus, glina, pergamin, jedwab, itp. jako nośnik informacji, tak może zniknąć i papier, jeśli zastąpimy go innym materiałem (np. syntetycznym) o podobnych właściwościach, tj. pozwalającym na podobną formę prezentacji informacji. Tak więc, chociaż nie są wypierane istniejące układy komunikacyjne (metody przekazu informacji), np. język gestów, mowa, pismo, druk, poczta, to zmianie ulegają poszczególne elementy tych układów, w szczególności materiały i narzędzia. Czynniki niezmienne tych układów związane są z czlowiekiem, a konkretnie z metodami odbioru przez niego informacji (słuch, wzrok), nadawania (aparat mowny, system mięśniowy) oraz wypracowanymi przez niego kodami (język, pismo alfabetyczne). Organizm człowieka nie jest bowiem podatny na zmiany w takim stopniu, w jakim ulega zmianie otaczające go środowisko.

Powiedzieliśmy, że wprowadzenie nowego medium z reguly ogranicza zakres funkcjonowania jednego ze starych środków komunikacji. Istnieją jednak sytuacje, kiedy wprowadzenie nowego medium zapewnia moźliwości dotychczas nie istniejące, tj. nie służy ulepszeniu dotychczasowych kanałów informacyjnych, lecz stwarza nowa jakość, nową formę przekazu. W takich przypadkach pojawienie się nowego środka komunikacji może przyczynić się do wzrostu popularności mediów tradycyjnych. Na przykład wynalazek i rozwój fotografii przyczynił się do wzrostu znaczenia i popularności gazety, wspieranej od tej pory odbitkami ilustrującymi tekst. Szczególnym przypadkiem podniesienia jakości i znaczenia wielu dotychczasowych systemów komunikacyjnych było wprowadzenie komputera. Stanowi on z jednej strony nowy środek komunikacji, a z drugiej służy ulepszeniu środków dotychczasowych, np. komputerowe centrale telefoniczne, zautomatyzowany proces produkcji książek, czasopism i filmów, itp. Zastosowanie komputerów w istniejących systemach komunikacyjnych prowadzi do ułatwienia, przyspieszenia i podniesienia jakości zapisu i przekazu, zwiększenia jego niezawodności oraz zmniejszenia kosztów.

Obecnie funkcjonuje niezależnie od siebie wiele układów komunikacyjnych, obok najstarszych - najnowsze. Człowiek współczesny wykorzystuje różne sposoby zdobywania informacji: sam przenosi nośnik z zapisaną informacja (np. wypożyczając książkę z biblioteki do domu), zleca przemieszczenie go instytucji w tej funkcji wyspecjalizowanej (korzystając z usług poczty), wysłuchuje odpowiednich programów radiowych lub telewizyjnych, telefonuje do wyspecjalizowanych służb informacyjnych, itp.

Nieustanne pojawianie się nowych środków komunikacji powoduje, że w pewnych okresach niektóre z nich stawały się dominujące, wiodące, by następnie ustapić miejsca nowym, bardziej efektywnym, tańszym lub lepiej zaspokajającym informacyjne potrzeby i oczekiwania społeczeństwa. Szczególnie widoczne było to przy pojawianiu się nowych, „rewolucyjnych" rozwiazzań technicznych prowadzących do nagłego przyspieszenia wymiany informacji lub radykalnego zwiększenia zasięgu jej oddziaływania. Sytuacja taka miała np. miejsce w XIX w., kiedy to dzięki nowym wynalazkom w przemyśle poligraficznym wzrosła znacznie produkcja czasopism (szybszy i tańszy proces ich wytwarzania), co doprowadziło do częściowego wyeliminowania korespondencji jako środka służącego wymianie informacji o 
najnowszych osiągnięciach naukowych między uczonymi. Z czasem, kiedy nowo powstałe media wysuwają się na pozycję wiodącą, stare media tracą swe dotychczasowe znaczenie, przechodząc z pozycji wszechstronnych na bardziej wyspecjalizowane, funkcjonując $w$ bardziej ograniczonym zakresie, $w$ którym najlepiej wypełniają postawione przed nimi zadanie. Tak jak przez wiele wieków wiodącą formą był przekaz ustny, następnie, przynajmniej w informacji naukowej zdominował go (choć nie wyparł) przekaz pisany (książka rękopiśmienna, korespondencja między uczonymi), stopniowo wypierany przez przekaz drukowany (ksią̇ka i czasopismo), tak obecnie jesteśmy świadkami stopniowego wychodzenia na pozycję wiodącą przekazów elektroniczych. Tak jak przed wiekami glina, papirus i pergamin przestały być głównym nośnikiem zapisu, tak teraz przewidywane jest powolne obumieranie „epoki papieru”. Minął wiek słowa drukowanego jako głównego środka utrwalania i przekazu informacji. Świat wkroczył bezpowrotnie w ere elektroniki i chociaż drukowane media z pewnością długo jeszcze nie znikną, to jednak zmieni się ich rola, znaczenie i zakres oraz proces wytwarzania. Już teraz można mieć subskrypcję elektroniczną niektórych gazet i czasopism, w domu zamiast z gazety można korzystać z teletekstu, a zamiast z drukowanych informatorów (książek telefonicznych, rozkładów jazdy, encyklopedii, bibliografii i katalogów) - z videotextu lub gotowych baz danych (online lub na dyskach optycznych). Tradycyjna książka coraz częściej zastępowana jest metalowym krążkiem - CD ROM-em.

\section{Tendencje rozwojowe środków komunikacji}

Sposoby przekazywania informacji są pochodną ogólnego rozwoju społeczeństwa ludzkiego, jego kultury, nauki i techniki. Kiedy mówimy o obecnej sytuacji w komunikacji od razu myślimy o technologii. Podstawowa bowiem różnica między najstarszymi formami przekazu informacji a obecnymi polega na odejściu od systemów bazujących na materiałach znajdowanych w przyrodzie oraz na naturalnych fizycznych zdolnościach człowieka (zmysły, system mięśniowy) i na coraz większym uzależnieniu się od urządzeń i technik sztucznie przez niego wytworzonych. Urządzenia te służą do „przedłużenia” jego zmysłów i zdolności percepcji wykorzystywanych w nadawaniu (np. mikrofon, telefon), odbieraniu (np. lornetka, mikroskop), zapamiętywaniu (dokumenty, czyli utrwalone zapisy), a obecnie i przetwarzaniu informacji (komputer).

Charakterystyczną cechą nowo powstających środków komunikacji jest więc odejście od naturalnych form jej przekazu, konieczność wykorzystywania coraz bardziej skomplikowanych urządzeń do odkodowywania informacji zapisanej za pomoca sygnałów nieodbieralnych przez człowieka (np. impulsów magnetycznych). Historia rozwoju ukladów komunikacyjnych pokazuje, że początkowo człowiek wykorzystywat do nadawania i odbioru informacji własne organy i zmysły, z czasem zaczał stosować pomocnicze narzędzia, najpierw bardzo proste, jak rylec, pióro, stopniowo coraz bardziej skomplikowane, jak maszyna do pisania, magnetofon, modem czy komputer. Obecnie przy większości środków przekazu potrzebne są urządzenia transformujące ich sygnały na odbieralne przez człowieka, np. czytnik do mikrofisz z tekstem tak pomniejszonym, że nieczytelnym gołym okiem. 
Urządzenia te z jednej strony zwiększają koszt, bo nawet jeśli sam nośnik jest tani, to aby mieć dostęp do informacji użytkownik musi zainwestować w kosztowny sprzęt dodatkowy umożliwiający jej odczyt, a z drugiej - wymagają od ludzi umiejętności ich obsługi, co czasami wymaga specjalnego przygotowania lub przeszkolenia. Prawdopodobnie czynnikiem determinującym przyjmowanie przez spoleczeństwo dalszych innowacji będzie tempo, w jakim przeciętny człowiek może się do nich przystosować. Jeżeli nowy środek wymaga interakcji (czyli czynnego uczestnictwa w przeciwieństwie do biernego odbioru, jak w przypadku radia czy telewizji), to tylko wtedy można liczyć na jego umasowienie i powszechne zaakceptowanie przez społeczeństwo, jeśli jest łatwy w użyciu, korzystanie z niego nie wymaga zbytniego wysiłku intelektuainego lub specjalistycznego wykształcenia. Fakt ten jest często nie dostrzegany przez twórców i projektantów, którzy uważają, że jeśli nowe medium daje duże możliwości (zwiększa zakres działania dotychczasowych, wprowadza nową jakość), a jego koszt mieści się w rozsądnych granicach, to zostanie automatycznie przez wszystkich zaakceptowany. Historia porażek niektórych nowych mediów (przynajmniej w początkowym okresie) wskazuje, że latwość ich stosowania jest czynnikiem bardzo istotnym. Stosunkowo długi proces upowszechniania komputerów spowodowany był m.in. obawą przed ich stosowaniem, związaną z trudnymi, wymagającymi specjalnego przygotowania programa$\mathrm{mi}$ (tzw. analfabetyzm komputerowy). Dlatego obecnie coraz większy nacisk kładzie się na łatwość obsługi nawet najbardziej skomplikowanych urządzeń, czego przejawem może być tendencja w zakresie softwar'u do tworzenia programów tzw. przyjaznych użytkownikowi, a więc sterujących użytkownikiem, podpowiadających mu i wspomagających na wszystkich etapach wykonywanych przez niego operacji, nie wymagających uprzedniego zapoznawania się z nimi lub przeszkolenia.

Wiąże się to $z$ następną widoczną tendencją w zakresie rozwoju środków przekazu - dażeniem do jak największej wygody w korzystaniu z nich. Dawniej odbiorca informacji musiał sam iść do miejsca jej przechowywania lub nadawania (np. do biblioteki, do księgarni, na pocztę, do szkoły), obecnie coraz częściej może z niej korzystać bez wychodzenia z domu lub z pracy (telewizja, radio, telegazeta, poczta elektroniczna, nauczanie za pośrednictwem urządzeń telekomunikacyjnych, itp.). Wygodzie użytkownika służą też wszelkiego typu urządzenia do zdalnego sterowania (telewizja, magnetowidem, teletekstem), tak aby nie musiał wstawać do zmiany programu, wybrania odpowiedniej strony, włączenia lub wyłączenia odbiornika. Zwiększeniu wygody służy też dostosowywanie czasu odbioru do życzenia użytkownika, np. dysponując teletekstem nie musi czekać na wyznaczone godziny nadawania wiadomości w radiu czy telewizji, posiadając magnetowid może nagrać wybrany program i obejrzeć go o dowolnej porze, a magnetofon - wybraną audycję radiową. Co więcej, urządzenia te umożliwiają mu nie tylko odbiór w wybranym przez niego czasie, ale wielokrotne odtwarzanie i możliwości dostosowania tempa odbioru do indywidualnej percepcji człowieka (np. w teletekście użytkownik może zatrzymać wybraną stronę na ekranie dowolną ilość czasu, podczas gdy przy dynamicznym przekazie telewizyjnym nie wszyscy zdażą przeczytać wyświetlane fragmenty tekstu). Informacja jest teraz na żądanie, wyświetlana wtedy, kiedy użytkownik ma na nią zapotrzebowanie. Dzięki posiadaniu urzą- 
dzeń do nagrywania użytkownik zyskał jeszcze pewną możliwość zenwania z ciągłością niektórych nośników lub dynamicznym charakterem nadawania, np. nie musi oglądać całego programu nagranego na taśmie magnetowidowej ( $w$ przeciwieństwie do programu telewizyjnego), fragmenty mniej go interesujące może szybciej przewinąć. Daje to większą możliwość indywidualnej selekcji informacji (doboru), podobnie jak w przypadku telegazety, gdzie nie musi wysłuchiwać wszystkich wiadomości lecz wyselekcjonować tylko te, które go rzeczywiście interesują. Możliwość dostosowania tempa nadawania do percepcji człowieka (różnej u różnych osób) charakterystyczna była tylko dla nośników statycznych (pismo, druk, obraz nieruchomy), nie posiadały jej natomiast dynamiczne środki przekazu (radio, telewizja), gdzie obraz lub mowa nadawane są ze stałą szybkością, bez względu na to, czy użytkownik zdąży je odebrać, czy nie. Utrwalanie przekazów dynamicznych za pomocą urządzeń posiadanych w domu (magnetofon, magnetowid) eliminuje częściowo tę wadę, gdyż umożliwia cofanie, wielokrotne odtwarzanie, zatrzymywanie obrazu lub nadawanie go w zwolnionym tempie.

Ogromny i wciąż wzrastający zasób informacji połączony z coraz większym zapotrzebowaniem na szybkie i aktualne dane stwarza potrzebę istnienia licznych niezależnych kanałów informacyjnych. Zwiększa się liczba i rośnie szybkość działania różnych środków przekazu. coraz większa różnorodność systemów przekazu umożliwia wybór takiego, który najlepiej wypełnia określone funkcje. Informacja ustna przekazywana może być obecnie bezpośrednio (rozmowa, wykład) lub liniami telefonicznymi, przez radio lub gotowe nagrania (taśmy, płyty). Rozmowa telefoniczna między wieloma osobami jednocześnie możliwa jest już od lat 30-tych, choć systemów takich przez długi czas nie wprowadzano do powszechnego użytku. Próba wprowadzenia wideofonu (telefon połączony z obrazem) pienwszy raz w 1927 r., a następnie na szerszą skalę w 1971 nie powiodła się. Przyczyną porażki był wysoki koszt (jedna rozmowa równała się ok. 250 rozmowom zwykłym) oraz czynniki psychologiczne. Coraz większą popularnością cieszą się natomiast audioi wideokonferencje, m.in. dlatego, że obecnie nawet bardzo drogie przesylanie obrazu liniami teiefonicznymi jest tańsze niż przejazd lub przelot uczestników na tradycyjną konferencję, nie wspominając o wygodzie i oszczędności w czasie. Innym rozwiazaniem są „konferencje” organizowane przy pomocy komputera i poczty elektronicznej. Mają one tę zaletę, że uczestnicy mogą odczytać poszczególne głosy w dyskusji o dowolnej porze, a nie jak w wideokonferencji osobiście w tym uczestniczyć (co jest szczególnie istotne, jeśli znajdują się w różnych strefach czasowych).

Obecnie większość z nas do przesylania wiadomości korzysta z poczty lub telegrafu; w instytucjach stosowane są teleksy. Służby te coraz częściej zastępowane są telefaksem, czyli urządzeniem powielającym (typu kserografu) o zdolnościach telekomunikacyjnych. Zaletą telefaksu w porównaniu z teleksem jest możliwość przesyłania nie tylko tekstów pisanych, lecz również diagramów, rysunków, fotografii, pisma ręcznego. Do przesyłania informacji tekstowej teleks wypierany jest coraz częściej przez procesory tekstu i pocztę elektroniczą. Procesor tekstu jest jakby inteligentną maszyną do pisania; umożliwia szybsze pisanie, latwiejszą korektęl $\mathrm{i}$ zmianę tekstu, wydruk $w$ dowolnej liczbie egzemplarzy $\mathrm{i}$ dowolnym 
drukiem, itp. Procesory tekstu mają ogromny wpływ na przyspieszenie i usprawnienie procesu wydawniczego i redakcyjnego czasopism i książek. Teksty z procesora mogą być wysyłane za pośrednictwem linii telefonicznych do innego komputera (np. od autora do redaktora, a następnie do wydawcy) i tam wyświetlane na ekranie i poddawane obróbce.

Każdy z funkcjonujących obecnie kanałów informacyjnych ma swoje specyficzne cechy i służy wypełnianiu określonych zadań. Wprowadzenie na dużą skalę telewizji doprowadziło do częściowego załamania się rynku kinowego (od $1947 \mathrm{r}$. nastapł spadek widzów o połowę). Telewizja przejęła większość funkcji rozrywkowych kina, umoźliwiając odbieranie tego w sposób tańszy i wygodniejszy. Jeszcze większe załamanie kina nastapiło po wprowadzeniu i upowszechnieniu magnetowidów i wypożyczalni kaset. Magnetowid nie tylko umożliwia oglądanie filmów w domu, ale daje także większą swobodę ich wyboru (w zależności od upodobań) i wielokrotne odtwarzanie. Kino funkcjonuje teraz w szczątkowej formie, specjalizując się w filmach, które nie najlepiej prezentują się na małym ekranie (widowiskowe, science-fiction) lub ze względów cenzuralnych nie są dopuszczane do masowego rozpowszechniania. Telewizja służy głównie do rozrywki, choć dość dużą rolę odgrywa w przekazywaniu bieżących wiadomości oraz programów kulturalnooświatowych. Dzięki wprowadzeniu serwisu teletekstowego i videoteksowego telewizja nabrała nowej jakości, stając się także środkiem przekazywania informacji, jaką do tej pory znaleźć można było głównie $w$ drukowanych informatorach. Wyraźnie widoczny jest trend do korzystania z telewizji w zakresie bieżących wiadomości, z której to roli wypiera gazety i radio. Radio, częściowo zachowując dotychczasowe funkcje, powoli przesuwa się do roli środka komunikacji dla zmotoryzowanych (kierowców) lub dla osób wykonujących prace mymagające zaangażowania ich kanału wizualnego lecz nie obciążające kanału słuchowego (np. prace domowe).

Radio ma tę przewagę nad systemem telefonicznym, że daje możliwość transmisji na duże dystanse i do miejsc, do których nie dochodzi sieć kablowa. Ograniczona jednak liczba zakresów fal (problem inferencji) sprawiła, że nadawanie drogą radiową od początku było rynkiem regulowanym centralnie. Pojawienie się radia spowodowało obawy o przetrwanie gazet (dlatego wydawcy gazet odmawiali początkowo zamieszczania programów radiowych), okazało się jednak, że nie tylko nie odebrało, ale przysporzyło im nowych czytelników. Radio nie wyeliminowało gazety, lecz w znacznym stopniu zmeniło jej charakter; zamiast dostarczania tylko wiadomości gazety przestawiły się na ich komentowanie, analizowanie, interpretowanie. Można jednak przypuszczać, że w przyszłości prasa codzienna (szczególnie o zasięgu ogólnokrajowym) wyjdzie bardzo osłabiona z walki z konkurencyjnymi serwisami telewizji, teletekstu i videoteksu (m.in. z powodu trudności z papierem). Także poczta prawdopodobnie podupadnie ze względu na koszt transportu na rzecz poczty elektronicznej i przekazów telefaksowych (nie tylko szybszych ale i tańszych). Można przypuszczać, że jeśli w grę wchodzić będzie czynnik czasu i dużej odległości, transmisja elektroniczna (telefaks i poczta elektroniczna) zwycięży, a jeśli czas będzie mniej istotny, a objętość przekazu duża (paczka, obszemy list) wybrana zostanie poczta tradycyjna (przy długich tekstach 
przekaz elektroniczny może okazać się za drogi w porównaniu z ceną usług pocztowych). Telefon wydaje się na razie nie zagrożony, choć z pewnością i tu nastapią pewne ograniczenia (na recz poczty elektronicznej lub telefaksu) i zmiany. Rozwój telefonu polega ostatnio na coraz wyższej jakości przekazu, usprawnieniu w obsłudze (automatyczne wykręcanie numeru, telefon bezprzewodowy, automatyczna sekretarka, itp.) oraz poszerzaniu zakresu zastosowań, np. telefon samochodowy, audiokonferencje. Książki i czasopisma ustąpią prawdopodobnie częściowo kasetom magnetofonowym, videotekstom, dyskom optycznym oraz wszelkim formom publikacji elektronicznych, a w niektórych zastosowaniach - mikroformom (dla informacji archiwalnej, rzadko wykorzystywanej a objętościowo dużej). Obecna postać ksiażki i czasopisma jest jednak na tyle atrakcyjna i wygodna (łatwość przenoszenia, wysoka jakość ilustracji, możliwość czytania bez dodatkowych urządzeń, itp.), że przetrwają one jeszcze z pewnością przez długi czas, zwłaszcza w naukach humanistycznych i społecznych, choć ich rola zostanie ograniczona do funkcji rekreacyjnych i oświatowych.

Charakterystycznym zjawiskiem w rozwoju środków komunikacji jest coraz częstsze wykorzystywanie urządzeń już istniejących (posiadanych przez odbiorców) i ich łączenie w celu utworzenia nowego medium (o nowej jakości, dla innych funkcji). Poczta elektroniczna wykorzystała komputery $i$ istniejące już sieci telefoniczne, serwis videoteksu połączył komputer z odbiornikiem telewizyjnym i telefonem, automatyczna sekretarka to połączenie telefonu z magnetofonem, itp. Daje to znaczne oszczędności, gdyż wykorzystuje zakupione już wcześniej urządzenia lub utworzoną już infrastrukturę, a jednocześnie pozwala użytkownikowi korzystać ze sprzętu, z którym już jest obeznany (brak bariery psychologicznej odstręczającej od nieznanych urządzeń).

Oceniając tendencje rozwojowe w zakresie komunikacji należy rozgraniczyć proces wytwarzania od procesu odtwarzania (odbioru)-informacji. Zagadnienie odbioru związane jest z formą prezentacji informacji. Otym, w jakiej formie (postaci) użytkownik odbierać będzie informacje decydować będzie jego wygoda, przyzwyczajenia (preferencje), koszt oraz charakter samej.informacji. Obecnie wciąż jeszcze najpowszechniejszą formą przekazu informacji naukowej jest nośnik papierowy z wydrukowanym tekstem (wzbogaconym o ilustracje lub wykresy graficzne), czasami stosowane są mikroformy i nośniki audiowizualne, lecz coraz częściej informacja prezentowana jest na monitore. Ta sama informacja (np. kursy walut, rozkład jazdy, program telewizyjny) dostarczana bywa w różnej postaci i na różnych nośnikach, np. w gazecie, w teletekście, jako informacja telefoniczna (specjalne służby), w serwisach online, w postaci drukowanej ksiażki, na dyskach optycznych, za pośrednictwem poczty elektronicznej, itp. Od użytkownika zależeć będzie wybór jednego z tych kanałów. Szczególnie wszechstronny i elastyczny, jeśli chodzi o różnorodność prezentacji informacji jest komputer; wyniki przetwarzania komputerowego mogą być podane $w$ formie słownej, obrazowej, $z$ dodaniem dźwięku i animacji, mogą być wydrukowane za pomocą drukarki lub systemu DTP na papierze (hard-copy), wyświetlone na monitorze, wydane w postaci mikrofilmu (urządzenia COM), itp., w zależności od przeznaczenia lub wymagań użytkownika. 
W zakresie wytwarzania (produkcji) źródeł informacji występują obecnie dwie przeciwstawne tendencje; $z$ jednej strony urządzenia służące utrwalaniu informacji są coraz bardziej skomplikowane, $z$ drugiej strony sam proces (obsługa tych urządzeń) coraz prostszy. Bardzo często urządzenia te $w$ miarę ich rozwoju przechodzą z rąk specjalistów w. ręce amatorów, z wyspecjalizowanych instytucji do biur lub domów. Fotografia, dzięki prostym w obsłudze aparatom i rozbudowanej sieci obsługi (wywoływanie filmów i sporządzanie odbitek) przeszła z rąk fotografów w ręce amatorów, magnetofon i dyktafon umożliwiły każdemu nagrywanie dokumentów dźwiękowych, wraz z narodzinami amatorskich kamer video każdy może zostać „wytwórcą filmowym”, a dzięki programom DTP (desktop publishing, drukowanie przy pomocy komputera) - także wydawcą lub drukarzem. Proces produkcji nie jest więc ograniczony do wyspecjalizowanych instytucji, przybliżony jest do użytkownika, coraz częściej może on sam produkować na własne potrzeby. Dą̇enie do jak najprostszej obsługi jest szczególnie widoczne na rynku komputerowym, wraz z rozwojem oprogramowania „przyjaznego użytkownikowi”. Coraz doskonalsze techniki uwielokrotniania dokumentów, powielania, kopiowania (proste w obsłudze kserograty, drukarki laserowe) zwiększają ponadto możliwości publikowania i rozpowszechniania informacji przez instytucje i osoby nie specjalizujące się w tych funkcjach. Możemy mówić o masowości informacji nie tylko w kategoriach jej odbioru, także w zakresie jej wytwarzania próg masowości został już przekroczony.

\section{Przypisy}

${ }^{1}$ Do oszczędności w zużyciu materiałów prowadzi także wspomniana już miniaturyzacja nośników.

${ }^{2}$ Najstarsza forma komunikowania się ludzi - język gestów, choć prymitywny i ograniczony funkcjonuje do dnia dzisiejszego (szczególnie przy zaangażowaniu emocjonalnym); czasami można mieć wrażenie, że posługujemy się tym językiem na poziomie podświadomości, większość jednak gestów ma charakter wyuczony, nabyty. 